\title{
Production and Health of Cows Given Monensin Prepartum and a High-Energy Diet Postpartum
}

\author{
A. Arieli, ${ }^{\star 1}$ U. Dicken, ${ }^{\star}$ I. Dagoni, $\dagger$ Y. Spirer, $\ddagger$ and S. Zamwel ${ }^{\star}$ \\ *The Hebrew University of Jerusalem, Faculty of Agricultural, Food and Environmental Quality Sciences, Rehovot 76100, Israel \\ †Hachaklait, Veterinary Services, PO 3039, Caesarea 38900, Israel \\ $\ddagger$ Mifalei Granot M.P., Hefer 38100, Israel
}

\section{ABSTRACT}

The object of this study was to evaluate the impact of monensin administration on the early lactation performance of cows maintained on a high-energy diet, and on health traits during the transition period. Cows $(\mathrm{n}=$ 168 ; parity $3.3 \pm 1.4$, initial body condition score $3.1 \pm$ 0.08 , and milk yield of $34.3 \mathrm{~kg} / \mathrm{d} \pm 0.9$ for multiparous cows in the preceding lactation) were divided into control and monensin treatment groups. A controlled-release capsule supplying $335 \mathrm{mg}$ of monensin/d for $95 \mathrm{~d}$ was inserted into the rumen of monensin-treated cows $30 \mathrm{~d}$ before the expected calving. Blood samples were obtained $2 \mathrm{~h}$ after feeding on $\mathrm{d} 14$ prepartum and on $\mathrm{d}$ 7,14 , and 50 postpartum. Plasma glucose concentration was $3 \%$ higher $(58 \pm 0.5$ vs. $56.4 \pm 0.5 \mathrm{mg} / \mathrm{dL})$ and $\beta$ hydroxybutyric acid was $17 \%(6.7 \pm 0.3$ vs. $8.0 \pm 0.3$ $\mathrm{mg} / \mathrm{dL}$ ) lower in monensin-treated than control cows. Plasma glucose was $10 \%$ higher $(60.0 \pm 0.6$ vs. $54.5 \pm$ $0.3 \mathrm{mg} / \mathrm{dL}$ ) and $\beta$-hydroxybutyric acid was $16 \%$ lower $(6.8 \pm 0.3$ vs. $7.9 \pm 0.2 \mathrm{mg} / \mathrm{dL})$ in primiparous than multiparous cows. Plasma nonesterified fatty acid concentration (measured only in primiparous cows) was $17 \%$ lower ( $287 \pm 15$ vs. $336 \pm 17 \mu \mathrm{Eq} / \mathrm{L}$ ) in treated than in control cows. Rate of ketosis incidence was $60 \%$ lower (8 vs. $21 \%$ ) in monensin-treated than in control cows, and the proportion of control cows that required a supply of glucogenic precursors was 3 -fold higher than in monensin-treated cows. The body condition score was $3.1 \pm 0.05,2.7 \pm 0.05$, and $2.4 \pm 0.05$ on d 60 prepartum and $\mathrm{d} 7$ and 50 postpartum, respectively, and was not affected by treatment. During the first 5 mo of lactation, milk yield was $7 \%$ higher $(37.6 \pm 0.6$ vs. $35.2 \pm 0.6 \mathrm{~kg} /$ d) in monensin-treated cows than in control cows. Our results showed that monensin administration, as a controlled-release capsule in prepartum cows, can be bene-

Received October 21, 2007.

Accepted January 14, 2008.

${ }^{1}$ Corresponding author: Arieli@agri.huji.ac.il ficial, even if these cows are maintained on a highenergy diet during the subsequent lactation.

Key words: high-energy diet, monensin, parity

\section{INTRODUCTION}

Transition cows are exposed to considerable modifications in their nutrient metabolism because of the increased energy and protein demands of the developing fetus and the switch to lactation. Because the energetic demands during the transition period (from $3 \mathrm{wk}$ before to $3 \mathrm{wk}$ after parturition) are larger than the cow's dietary energy intake, substantial adipose tissue mobilization must occur, with an inevitable increase in the rate of metabolic disorders (Overton and Waldron, 2004), leading to a subsequent decrease in productivity and profitability. Solutions for improving the energy balance have been aimed toward decreasing the energy deficit during this period. Nevertheless, specific feeding strategies, for example, those attempting to decrease body fat mobilization, prime for body fat mobilization, or prime the rumen for increased intake, have had only limited success (Friggens et al., 2004).

In contrast, supplying these cows with a gluconeogenic precursor, such as propylene glycol, has generally been effective in decreasing the rate of metabolic disorders (Nielsen and Ingvartsen, 2004). Improving the energy balance of transition cows can be accomplished by administering ionophores such as monensin (MON), which exert their effect by modifying rumen fermentation. The beneficial effect of MON might be attributed to several different mechanisms: an increased propionate:acetate ratio in the rumen, decreased energy loss through methane production, and decreased digestion of protein and starch in the rumen, with subsequent improved utilization of these nutrients in the small intestine (McGuffey et al., 2001). These effects lead to decreased blood NEFA and BHBA concentrations, an increase in glucose status, and a more positive energy balance (Duffield et al., 2003). When provided postpartum, MON may increase the milk yield of dairy cattle (Granzin and Dryden, 1999), although at that stage, its 
effect is less pronounced. According to Ipharraguerre and Clark (2003), significant effects of increased milk yield were reported in $50 \%$ of the surveyed experiments.

Treatment of transition cows with a MON controlledrelease capsule (CRC), supplying MON for approximately $100 \mathrm{~d}$ (McGuffey et al., 2001), enabled producers to treat periparturient cows, with the advantage of manipulating metabolism during the prepartum and postpartum stages as well. Most studies relating to the application of an MON CRC in dairy cattle have been carried out in cows consuming low- to medium-energy diets (Ipharraguerre and Clark, 2003). Tedeschi et al. (2003) suggested that the potential effect of MON on increasing propionate production and reducing methane dissipation was limited in cows maintained on concentrated diets. Nevertheless, MON CRC administration can exert a positive effect on the energy metabolism of high-energy-fed dairy cows because of a reduced rate of metabolic disorders around parturition and a reduction in excessive ruminal fermentation. In the current study, we examined the impact of MON CRC administration to periparturient cows on health traits and subsequent milk production when the cows were fed a highenergy diet.

\section{MATERIALS AND METHODS}

\section{Feeding and Management of Cows}

The Hebrew University Animal Care Committee approved all experimental procedures involving animals. The trial was conducted at the dairy barn of the communal farm of Nir Galim, Israel, from March 2003 to March 2004. Nonlactating Israeli Holstein cows from first lactation $(\mathrm{n}=40)$, second lactation $(\mathrm{n}=39)$, and third and greater lactations ( $n=89$ ) were used. Once monthly, a list of milking cows expected to calve within the subsequent 2 mo was divided randomly into 2 equal sets based on lactation number, DIM, previous lactation milk yield, and BCS at drying off. These sets were randomly assigned to control and treatment groups. Primiparous cows were enrolled according to their BCS only. For both treatments, the initial BCS was 3.1 and $3.0(\mathrm{SE}=0.08)$ in primiparous and multiparous cows, respectively. Milk yield of the preceding lactation in multiparous cows was $34.4 \mathrm{~kg} / \mathrm{d}$ in control cows and $34.2 \mathrm{~kg} / \mathrm{d}$ in MON-treated cows $(\mathrm{SE}=0.9)$, and the lactation number in both treatments was $3.3 \pm 1.4$.

A CRC supplying $335 \mathrm{mg}$ of MON/d for $95 \mathrm{~d}$ (CRC, Elanco, Guelph, Canada) was administered orally to MON-treated cows $30 \mathrm{~d}$ before the expected calving. Records of cows treated with MON were not accessible to the farm workers or observation staff, who were blinded to treatments throughout the study period.
Table 1. Ingredient and chemical composition of diets fed to periparturient and lactating cows

\begin{tabular}{lccc}
\hline Composition & Far-off dry $^{1}$ & Close-up dry $^{2}$ & Postpartum \\
\cline { 2 - 3 } & \multicolumn{3}{c}{ \% of DM } \\
\cline { 2 - 4 } Ingredient composition & & 30.4 & \\
Wheat hay & 43.1 & 12.2 & 25.9 \\
Wheat silage & 17.4 & 13.6 & \\
Wheat straw & 19.3 & 13.8 & 12.5 \\
Barley grains & 4.4 & 15.1 & 25.8 \\
Corn grains & 5.2 & 14.9 & 11.1 \\
Soybean meal & 10.6 & & 6.5 \\
Corn gluten feed & & & 2 \\
Whole cottonseeds & & & 2.8 \\
Cane molasses & & 14.5 & 6.7 \\
Soyhulls & & 33.5 & 16.6 \\
Chemical composition & & \\
CP & 12 & 38.8 & 29.6 \\
NFC & 22.0 & 2.0 & 4.6 \\
NDF & 51.9 & 0.30 & 0.9 \\
Fat & 1.8 & 0.27 & 0.45 \\
Ca & 0.40 & 1.55 & 1.77 \\
P & 0.24 & & \\
NE & & & \\
\hline
\end{tabular}

${ }^{1}$ Far-off dry period diet was fed from drying off until $28 \mathrm{~d}$ before expected parturition.

${ }^{2}$ Close-up dry period diet was fed from $28 \mathrm{~d}$ before expected parturition.

${ }^{3}$ Postpartum diet contained 180,000 units of vitamin A, 1,000 units/ $\mathrm{g}$ of vitamin $\mathrm{E}$, and $0.375 \%$ salt. Far-off and close-up diets contained 100,000 units of vitamin A, $0.3 \%$ salt, $60 \mathrm{~g}$ of manganese, $60 \mathrm{~g}$ of zinc, $20 \mathrm{~g}$ of copper, $1.2 \mathrm{~g}$ of iodine, and $0.2 \mathrm{~g}$ of cobalt (units per ton).

Prepartum and postpartum cows of both experimental groups were maintained together in the same open sheds ( 2 sheds for prepartum cows and 4 sheds for lactating cows); fans were available in each shed to cool the cows in the summer. Daily feed was provided at approximately 0730,1000 , and at $1500 \mathrm{~h}$, and cows had free access to feed (Table 1) and water. Cows were milked 3 times daily at approximately 0600, 1400, and $2100 \mathrm{~h}$, and individual milk yields were recorded. The BCS (Wildman et al., 1982) was evaluated on d 60 prepartum and on $d 7$ and 50 postpartum.

\section{Sample Collection, Measurements, and Analyses}

Milk production was recorded for each milking by automatic meter (Afimilk, Zaham Afikim, Israel). Individual daily milk production was calculated and used to compute mean weekly milk yields. Milk yields for the first $18 \mathrm{wk}$ of lactation are reported. Milk samples were collected every month during the experimental periods from each daily milking and composited by milk volume.

Blood samples for plasma composition analysis were collected via jugular venipuncture into evacuated tubes (BD Vacutainer, Belliver Industrial Estate, Plymouth, UK). Blood was sampled approximately $2 \mathrm{~h}$ after feed- 
ing at $14 \mathrm{~d}$ prepartum and at 7,14 , and $50 \mathrm{~d}( \pm 1)$ postpartum. Plasma-collection tubes for glucose analysis contained sodium fluoride- $\mathrm{K}_{3} \mathrm{EDTA}$, and plasma tubes for other analyses contained sodium heparin. Plasma tubes were placed on ice immediately after sampling, centrifuged at $4^{\circ} \mathrm{C}$ at $3,300 \times g$ for 15 min within $1 \mathrm{~h}$ of collection, and stored at $-20^{\circ} \mathrm{C}$ for later analysis.

Milk samples $(20 \mathrm{~mL})$ from 3 consecutive milking sessions were analyzed by the Israeli Cattle Breeders Association (Milk Recording Laboratory, Industrial Area, Caesarea, Israel) for fat, CP, lactose, urea N, and SCC by midinfrared spectrometry (MilkoScan FT 6000; Foss Electric, Hillerød, Denmark). Plasma was analyzed for urea N (PUN; Coulomb and Favereau, 1963), glucose (Raichem Kit 85188; Raichem, Columbia, MD), NEFA (NEFA-C kit; Wako, Richmond, VA), BHBA (Sigma kit 310-A; Sigma Chemical Co., St. Louis, MO), and aspartate aminotransferase (AST; AST kit; Raichem Diagnostics Co., San Diego, CA).

\section{Animal Health}

A veterinarian recorded disease and health conditions throughout the experiment. The following health disorders were recorded for all cows: ketosis (a high level of ketones detected in the urine by KetoStrips, Bayer Co., Dublin, Ireland), retained placenta (a placenta that was retained for $>12 \mathrm{~h}$, verified by vaginal exploration), and metritis (diagnosed by vaginal exploration). Animals suspected of displaced abomasum were subjected to veterinary examination for verification and surgery. Traits used to evaluate health status included general demeanor, rectal temperature, and milk production. Sick cows were treated with antibiotics. Cows from both groups that were diagnosed as ketotic were injected with $50 \%$ dextrose $(500 \mathrm{~mL}$, i.v.) and drenched with $300 \mathrm{~g}$ of propylene glycol for 3 consecutive days.

\section{Statistical Analysis}

Statistical analysis was performed by a repeated measures method using the PROC MIXED procedure of SAS (v. 9.1; SAS Inst. Inc., Cary, NC). The model analyzed concentration of metabolites in the blood plasma:

$Y_{\mathrm{ij}}=\mu+T_{\mathrm{i}}+P_{\mathrm{j}}+C_{\mathrm{ijk}}+D_{1}+T P_{\mathrm{ij}}+T D_{\mathrm{il}}+T P D_{\mathrm{ijl}}+\varepsilon_{\mathrm{ijkl}}$,

where $Y_{\mathrm{ij}}$ is the dependent variable, $\mu$ is the overall mean, $T_{\mathrm{i}}$ is the effect of treatment $(\mathrm{i}=1,2), P_{\mathrm{j}}$ is the effect of parity (primiparous or multiparous cows), $\mathrm{C}_{\mathrm{ijk}}$ is the effect of cow k in treatment i and parity $\mathrm{j}, D_{\mathrm{l}}$ is the effect of sampling date $(1=1,2,3$, or 4$), T P$ is the effect of a treatment $\times$ parity interaction, $T D$ is the effect of a treatment $\times$ sampling date interaction, $T P D$ is the effect of a treatment $\times$ parity $\times$ sampling date interaction, and $\varepsilon_{\mathrm{ijkl}}$ is the within-cow residual error.

A similar model was used to analyze monthly milk yield and the percentage and yield of milk constituents. The variable $D$ was the effect of milk sampling month $(l=1,2, \ldots$, or 5$)$ for analyzing the weekly milk yield (averaged of daily milk data; $1=1,2, \ldots$, or 18 ), and $\operatorname{BCS}(1=1,2,3)$.

The comparisons for the main effects were performed on the least squares means. For most traits, the interaction terms were not significant $(P>0.05)$, in which case only the main effects are reported. When the $T P, T D$, or TPD effect was significant, least squares means were compared at each time point by contrast $t$-tests.

Incidence of health problems and incidence of glucogenic precursor application were analyzed for treatment effects by using the FREQ procedure of SAS with $\chi^{2}$ or Fisher's exact tests.

\section{RESULTS AND DISCUSSION}

\section{Plasma Metabolites}

Concentrations of blood metabolites were measured concurrently with MON CRC application; hence, the differences between MON-treated and control cows represent a direct effect of MON. The effects of the interactions were not significant. Concentrations of plasma glucose, BHBA, NEFA, and AST activity revealed a clear temporal pattern (Figures 1 and 2).

\section{Glucose}

Plasma glucose was $3 \%$ higher in MON-treated (58.0 $\pm 0.5 \mathrm{mg} / \mathrm{dL})$ than in control cows $(56.4 \pm 0.5 \mathrm{mg} / \mathrm{dL}, P$ $<0.02)$ and $10 \%$ higher in primiparous $(60.0 \pm 0.6 \mathrm{mg} /$ $\mathrm{dL})$ than in multiparous cows $(54.4 \pm 0.4 \mathrm{mg} / \mathrm{dL}, P<$ 0.001 ). Plasma glucose concentration was $60.5 \pm 0.5$, $51.5 \pm 0.6,53.2 \pm 0.5$, and $57.7 \pm 0.5 \mathrm{mg} / \mathrm{dL}$ at $-14,7$, 14 , and $50 \mathrm{~d}$, respectively $(P<0.001)$. Our data support previous studies in which MON treatment did not affect prepartum glucose concentration (Duffield et al., 1998, 2003; Vallimont et al., 2001). The postpartum diet (Table 1) was formulated according to NRC (2001) recommendations.

Here, in both treatments, plasma glucose was higher in primiparous than in multiparous cows by $8 \%(63.0$ \pm 0.7 vs. $60.0 \pm 0.6 \mathrm{mg} / \mathrm{dL}$ ), $12 \%$ (56.3 \pm 1.3 vs. $50.3 \pm$ $0.6 \mathrm{mg} / \mathrm{dL}), 16 \%(59.8 \pm 0.8$ vs. $51.5 \pm 0.5 \mathrm{mg} / \mathrm{dL})$, and $5 \%(59.8 \pm 1.0$ vs. $57.1 \pm 0.6 \mathrm{mg} / \mathrm{dL})$ on d 14 prepartum and $d 7,14$, and 50 postpartum, respectively. This finding probably reflects the lower demand of primiparous 
A

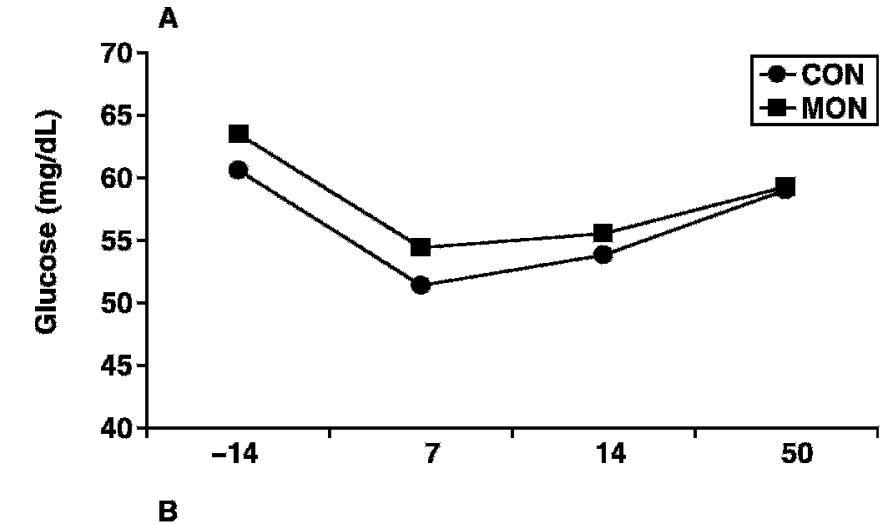

B

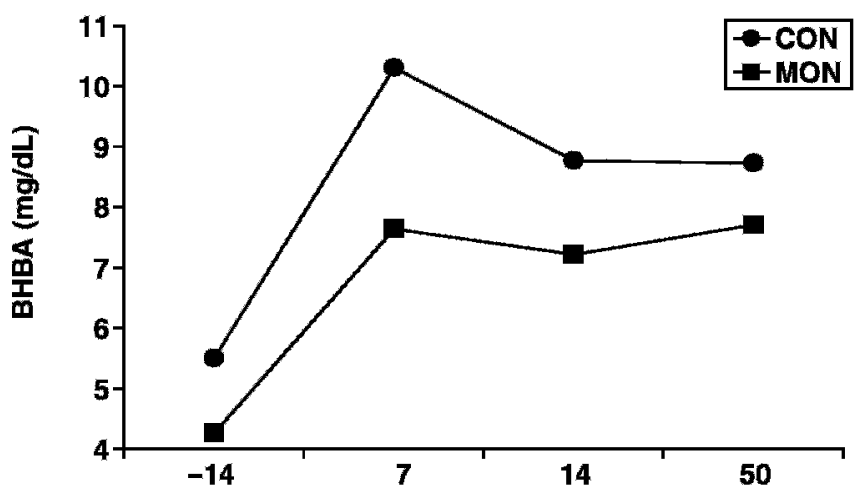

c

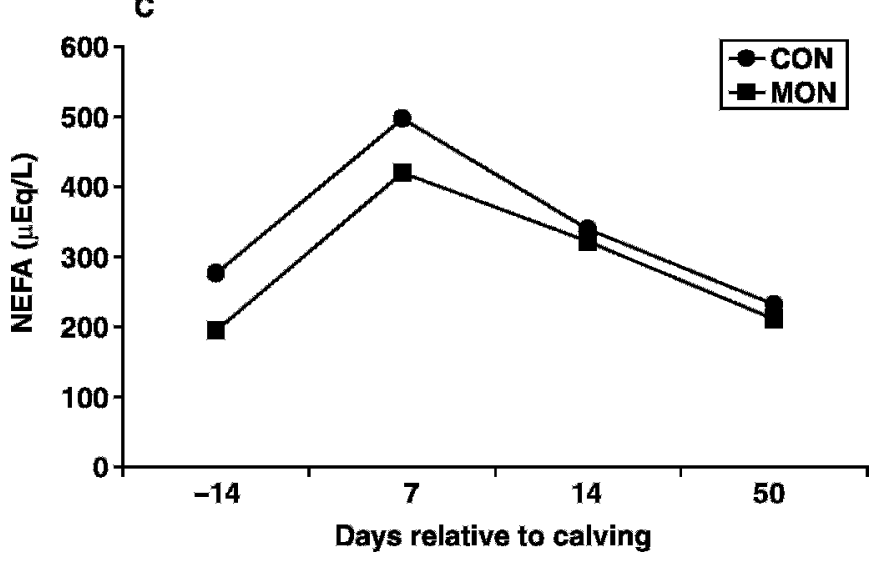

Figure 1. Least squares means of plasma concentrations of glucose (A), BHBA (B), and NEFA (only in multiparous cows; C) in control cows $(\mathrm{CON})$ and cows treated with a monensin (MON) controlledrelease capsule 1 mo before parturition. Standard error values in CON and MON-treated cows were 2.8 and 2.7 for glucose, 0.4 and 0.4 for BHBA, and 18 and 17 for NEFA, respectively.

cows as compared with multiparous cows for milk lactose synthesis.

\section{$B H B A$ and NEFA}

Plasma BHBA concentration was $16 \%$ lower in MONtreated cows than in control cows $(6.7 \pm 0.3$ vs. $8.0 \pm$ $0.3 \mathrm{mg} / \mathrm{dL}, P<0.001)$ and in multiparous cows $(7.9 \pm$
A

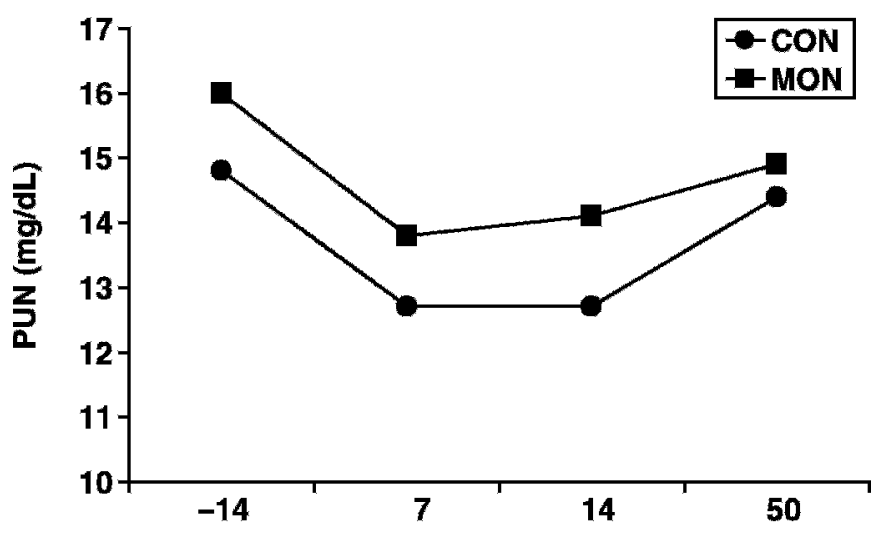

B

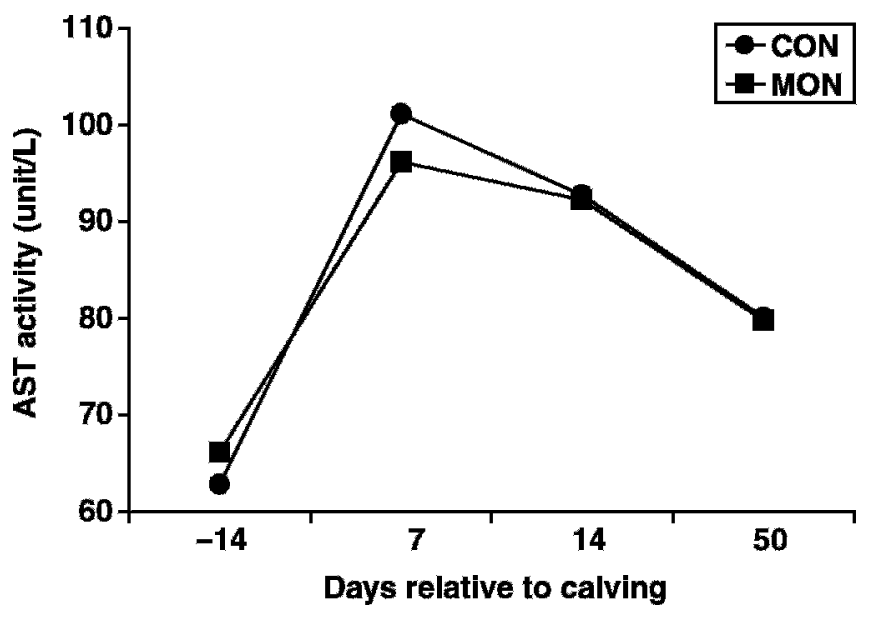

Figure 2. Least squares means of plasma concentrations of plasma urea nitrogen (PUN; A) and aspartate aminotransferase activity (AST; B) in control cows (CON) and cows treated with a monensin (MON) controlled-release capsule 1 mo before parturition. Standard error values in $\mathrm{CON}$ and MON-treated cows were 0.4 and 0.4 for PUN, and 2.8 and 2.7 for AST, respectively.

$0.2 \mathrm{mg} / \mathrm{dL})$ than in primiparous cows $(6.8 \pm 0.3 \mathrm{mg} / \mathrm{dL}$, $P<0.01$ ). Plasma BHBA concentration was $5.0 \pm 0.1$, $9.1 \pm 0.4,8.1 \pm 0.3$, and $8.4 \pm 0.2 \mathrm{~g} / \mathrm{dL}$ on $\mathrm{d}-14,7,14$, and 50, respectively $(P<0.001)$. The effect of MON is in agreement with the reports of Stephenson et al. (1997), Duffield et al. (1998), and Melendez et al. (2004). Plasma NEFA concentration (measured only in multiparous cows) was $17 \%$ lower in MON-treated cows (287 $\pm 16 \mu \mathrm{Eq} / \mathrm{L})$ relative to control cows $(336 \pm 17 \mu \mathrm{Eq} / \mathrm{L}$, $P<0.04$ ). Plasma NEFA concentration was $277 \pm 28$, $497 \pm 27,339 \pm 28$, and $231 \pm 29 \mu \mathrm{Eq} / \mathrm{L}$ on $\mathrm{d}-14,7,14$, and 50, respectively $(P<0.001)$.

Our data support a study in which MON administration did not affect NEFA concentration, whereas plasma BHBA concentration was reduced consistently (Ipharraguerre and Clark, 2003). Increased hepatic 
Table 2. Health problems diagnosed between 4 wk prepartum and 7 wk postpartum

\begin{tabular}{lccc}
\hline & \multicolumn{2}{c}{ Treatment } & \\
\cline { 2 - 3 } Item & Control & Monensin & $P$-value \\
\hline $\mathrm{n}$ & 81 & 87 & \\
Trait, \% of cases & & & \\
$\quad$ Ketosis & 21.0 & 8.0 & 0.026 \\
Retained placenta & 7.4 & 3.0 & 0.316 \\
Uterine infection & 13.6 & 12.6 & 1.000 \\
Propylene glycol & 32.1 & 11.5 & 0.032 \\
\hline
\end{tabular}

conversion of NEFA to ketone bodies during the transition period was considered a strategy to compensate for insufficient intake of glucose precursors (Drackley et al., 2001). In our study, there was a negative correlation between plasma BHBA and glucose concentrations $(\mathrm{r}=$ $-0.53,-0.47$, and -0.54 for $\mathrm{d} 7,14$, and 50 postpartum, respectively; $\mathrm{n}=130, P<0.001)$. These correlations are compatible with the potential of MON to increase the supply of glucose precursors.

\section{Urea}

Concentration of PUN tended to be affected by treatment $(13.9 \pm 0.3 \mathrm{mg} / \mathrm{dL}$ in control cows vs. $14.7 \pm 0.3$ $\mathrm{mg} / \mathrm{dL}$ in MON-treated cows, $P=0.09$ ), but not by parity $(P>0.1)$. Concentration of PUN was $15.7 \pm 0.3,13.5 \pm$ $0.3,13.7 \pm 0.2$, and $14.9 \pm 0.3 \mathrm{mg} / \mathrm{dL}$ on $\mathrm{d}-14,7,14$, and 50 , respectively $(P<0.001)$.

\section{AST Activity}

Aspartate aminotransferase activity was $66.1 \pm 1.0$, $100.2 \pm 2.6,94.2 \pm 1.6$, and $81.5 \pm 1.4$ units $/ \mathrm{mL}$ on $\mathrm{d}$ $-14,7,14$, and 50 , respectively $(P<0.001)$. Activity of AST was not affected by treatment or by parity. In contrast, a large-scale study using approximately 1,000 cows found a significant, albeit subtle, effect of $\mathrm{MON}$, lowering AST activity during the first 2 wk postcalving (Duffield et al., 1998). Others (Ramanzin et al., 1997; Juchem et al., 2004) did not observe any effect of MON on AST in postcalving cows. Thus, AST activity appears to be a weak indicator for transition in the energy state of the cow.

\section{Health Conditions and BCS}

Frequency of health disorders and rates of propylene glycol application are shown in Table 2. Rate of ketosis incidence was 60\% lower in MON-treated than in control cows. Likewise, the rate of cows treated with propylene glycol supplementation was $62 \%$ lower in MONtreated than in control cows. In previous studies, MON

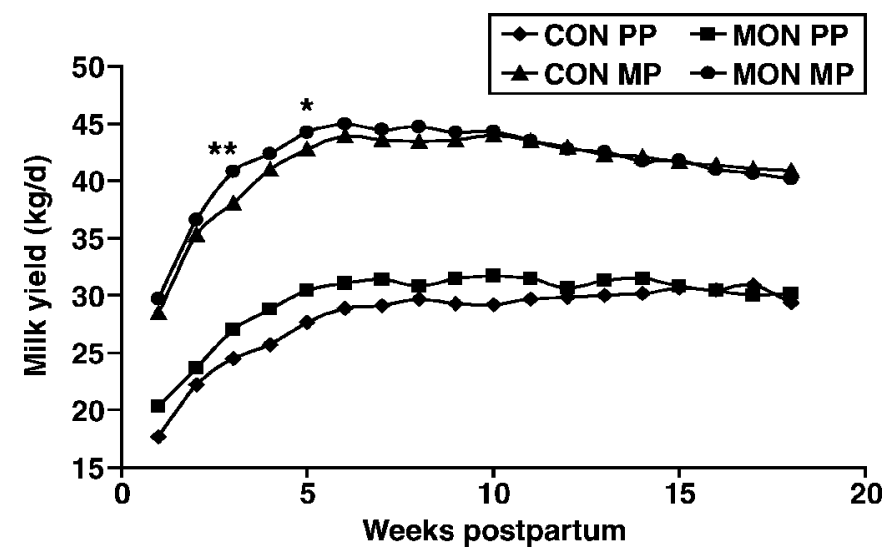

Figure 3. Least squares means of weekly milk yield in control cows $(\mathrm{CON})$ and cows treated with a monensin (MON) controlledrelease capsule 1 mo before parturition. Pooled SEM values were 0.7 and 0.4 for primiparous (PP) and multiparous (MP) cows, respectively. $* * P<0.01, * P<0.05$.

decreased the prevalence of ketosis and improved rumen health in the early-lactating dairy cow (Duffield et al., 1998, 2002; Green et al., 1999). Indeed, compared with MON-treated cows, the proportion of control cows that required a supply of glucogenic precursors was 3fold higher. Metabolic disorders (i.e., milk fever and ketosis) usually occurred during the first 2 wk postpartum and were caused by low DMI and negative energy balance (Goff and Horst, 1997), yet there was no significant effect of MON on the incidence rate of retained placentas or uterine infections.

The BCS was not affected by treatment or parity. The BCS was $3.1 \pm 0.04,2.6 \pm 0.05$, and $2.5 \pm 0.04$ on $d$ 60 prepartum and $d 7$ and 50 postpartum, respectively.

\section{Milk Yield and Composition}

Weekly milk yield tended to be higher in MONtreated than in control cows $(35.6 \pm 0.6$ vs. $34.2 \pm 0.6$ $\mathrm{kg} / \mathrm{d}, P<0.09)$, and it was higher in multiparous (41.1 $\pm 0.4 \mathrm{~kg} / \mathrm{d})$ than in primiparous $(28.8 \pm 0.7 \mathrm{~kg} / \mathrm{d})$ cows $(P<0.001)$. Effects of parity, week, and a treatment $\times$ parity $\times$ week interaction were significant $(P<0.001)$.

Weekly milk production during wk 1 to 18 in primiparous and multiparous cows is shown in Figure 3. Multiparous MON-treated cows produced $1.7 \mathrm{~kg}$ more milk on wk 3 and 5 than did their counterparts. In multiparous cows during the other weeks, and in primiparous cows throughout the entire experimental period, milk yield was similar among treatments. In primiparous cows, peak yield was attained in wk 17 in control cows compared with wk 10 in MON-treated cows, with respective milk production of $30.2 \pm 1.4$ and $31.7 \pm 1.3$ $\mathrm{kg} / \mathrm{d}$. In multiparous cows, peak yield was attained at 
Table 3. Least squares means of milk yield and composition for the first 5 mo of lactation of control cows and cows treated with a monensin controlled-release capsule 1 mo before parturition

\begin{tabular}{|c|c|c|c|c|c|c|c|c|}
\hline \multirow[b]{2}{*}{ Measure } & \multicolumn{3}{|c|}{ Treatment } & \multicolumn{3}{|c|}{ Parity $^{1}$} & \multicolumn{2}{|c|}{$P$-value } \\
\hline & Control & Monensin & $\mathrm{SE}$ & $\mathrm{PP}$ & MP & SE & Treatment & Parity \\
\hline Milk yield & 35.2 & 37.6 & 0.6 & 30.6 & 42.1 & 0.41 & 0.007 & 0.000 \\
\hline Fat, \% & 3.40 & 3.42 & 0.04 & 3.36 & 3.46 & 0.03 & 0.675 & 0.064 \\
\hline Protein, \% & 2.95 & 2.95 & 0.02 & 2.98 & 2.91 & 0.02 & 0.939 & 0.063 \\
\hline Lactose, $\%$ & 4.85 & 4.87 & 0.02 & 4.97 & 4.75 & 0.02 & 0.372 & 0.000 \\
\hline Fat, g & 1,201 & 1,273 & 21 & 1,016 & 1,458 & 20 & 0.019 & 0.000 \\
\hline Protein, g & 1,032 & 1,088 & 15 & 898 & 1,222 & 15 & 0.010 & 0.000 \\
\hline Lactose, $\mathrm{g}$ & 1,706 & 1,822 & 28 & 1,504 & 2,023 & 30 & 0.005 & 0.000 \\
\hline MUN, mg/dL & 11.9 & 12.3 & 0.4 & 10.6 & 13.5 & 0.3 & 0.471 & 0.000 \\
\hline $\mathrm{SCC}, \log$ cells $/ \mu \mathrm{L}$ & 1.90 & 1.90 & 0.05 & 1.84 & 1.97 & 0.05 & 0.959 & 0.148 \\
\hline
\end{tabular}

${ }^{1}$ Parity: $\mathrm{PP}=$ primiparous cows; $\mathrm{MP}=$ multiparous cows.

wk 6 , with milk yields of 43.9 and $45.0 \mathrm{~kg} / \mathrm{d}$ in control and MON-treated cows, respectively. Analysis of Figure 3 revealed that MON increased milk yield during wk 3 and 5 of lactation for multiparous cows. The effect of MON on the milk yield of multiparous cows diminished after $5 \mathrm{wk}$, which suggests that MON had no carryover effect beyond the period of its application. A similar conclusion was reached by Melendez et al. (2004), based on a time course of MON effect on blood metabolite concentration.

Ipharraguerre and Clark (2003) reviewed the effects of ionophore administration on milk production under various diets (concentrate-to-forage ratios) and physiological stages (starting either before or after parturition). Ionophore administration to dairy cows either did not affect (18 experiments) or increased (14 experiments) milk production. Of those studies that resulted in a positive response, the effect of MON on milk yield in the current study was within the range of $1.5 \mathrm{~kg} / \mathrm{d}$.

Daily milk yield based on monthly milk yield was affected by treatment $(P<0.001)$, parity, and month $(37.6 \pm 0.7,41.6 \pm 0.7,41.2 \pm 0.7,39.5 \pm 0.6$, and 37.9 $\pm 0.6 \mathrm{~kg} / \mathrm{d}$ in 1 to $5 \mathrm{mo}$, respectively, $P<0.0001$ ). During the first 5 mo of lactation, milk yield was $7 \%$ higher in MON-treated than in control cows (Table 3). The treatment $\times$ parity interaction was not significant.

Compositions of fat, protein, lactose, MUN, and SCC were similar in both treatments. Nevertheless, yields of milk components (fat, 6\%; protein, 6\%; lactose, $7 \%$ ) were higher in MON-treated cows. The increased yield of milk constituents in these cows simply reflected the increase in milk yield. Ipharraguerre and Clark (2003) reported that milk fat concentration was reduced by $4.5 \%$ in MON-treated cows, apparently via changes mediated by biohydrogenation intermediates. Nevertheless, analysis of the data set presented by Ipharraguerre and Clark (2003) suggests that the effect of MON on the decrease in milk fat percentage was proportional to the concentration of the control, and MON-induced reduction was minimized when the control cow milk fat concentration was approximately $3 \%$, as was the case in the present study.

The concentration of MUN was $28 \%$ higher in multiparous than in primiparous cows (Table 3 ). This finding disagrees with earlier reports in which no parity effect on MUN was observed (Davidson et al., 2003; Johnson and Young, 2003). The apparent between-study variation in parity effect might be explained by the dependence of MUN on various factors (e.g., milk yield, season, lactation stage; Wattiaux et al., 2005).

\section{CONCLUSIONS}

This is the first study to examine the impact of prepartum MON CRC administration to dairy cows fed a high-energy diet postpartum. With this diet, the advantage of MON CRC was demonstrated at both the prepartum and postpartum stages. The higher production of milk, protein, fat, and lactose during the first $7 \mathrm{wk}$ of lactation and the better health and energy status of treated cows indicate that, under conditions of a highenergy lactation diet, there was an advantage to MON application. Under the experimental protocol, milk fat percentage was unaffected by MON. When the results from the present study are combined with those in the literature, the benefits of MON are indicated, particularly when an MON CRC is introduced to periparturient cows.

\section{ACKNOWLEDGMENTS}

The authors acknowledge the Israeli Cattle Breeder Board (Caesarea, Israel) and S. H. Design Engineering Ltd. (Herzelia, Israel) for financial support and Elanco for supplying the CRC. The authors would like to thank the dairy staff of Nir Galim for their cooperation. 


\section{REFERENCES}

Coulomb, J. J., and L. Favereau. 1963. A simple semi-micro method for colorimetric determination of urea. Clin. Chem. 9:102-108.

Davidson, S., B. A. Hopkins, D. E. Diaz, S. M. Bolt, C. Brownie, V. Fellner, and L. W. Whitlow. 2003. Effect of amounts and degradability of dietary protein on lactation, nitrogen utilization, and excretion in early lactation Holstein cows. J. Dairy Sci. $86: 1681-1689$.

Drackley, J. K., T. R. Overton, and G. N. Douglas. 2001. Adaptation of glucose and long-chain fatty acids metabolism in liver of dairy cows during the periparturient period. J. Dairy Sci. 84:100-112.

Duffield, T., R. Bagg, L. DesCoteaux, E. Bouchard, M. Brodeur, D. DuTremlay, G. Keefe, S. LeBlanc, and P. Dick. 2002. Prepartum monensin for the reduction of energy associated disease in prepartum dairy cows. J. Dairy Sci. 85:397-405.

Duffield, T. F., S. LeBlanc, R. Bagg, K. Leslie, J. Ten Hag, and P. Dick. 2003. Effect of a monensin controlled release capsule on metabolic parameters in transition dairy cows. J. Dairy Sci. 86:1171-1176.

Duffield, T. F., D. Sandals, K. E. Leslie, K. Lissemore, B. W. McBride, J. H. Lumsden, P. Dick, and R. Bagg. 1998. Effect of prepartum administration of monensin in a controlled-release capsule on postpartum indicators in lactating dairy cows. J. Dairy Sci. 81:2354-2361.

Friggens, N. C., J. B. Andersen, T. Larsen, O. Aaes, and R. J. Dewhurst. 2004. Priming the dairy cow for lactation: A review of dry cow feeding strategies. Anim. Res. 53:453-473.

Goff, J. P., and R. L. Horst. 1997. Physiological changes at parturition and their relationship to metabolic disorders. J. Dairy Sci. 80:1260-1268

Granzin, B. C., and G. M. Dryden. 1999. The effect of monensin on milk production and levels of metabolites in blood and rumen fluid of Holstein-Friesian cows in early lactation. Aust. J. Exp. Agric. 39:933-940.

Green, B. L., B. W. McBride, D. Sandals, K. E. Leslie, R. R. Bagg, and P. Dick. 1999. The impact of monensin controlled-release capsule on subclinical ketosis in the transition dairy cow. J. Dairy Sci. 82:333-342.

Ipharraguerre, I. R., and J. H. Clark. 2003. Usefulness of ionophores for lactating dairy cows: A review. Anim. Feed Sci. Technol. 106:39-57.
Johnson, R. G., and A. J. Young. 2003. The association between milk urea nitrogen and DHI production variables in Western commercial dairy herds. J. Dairy Sci. 86:3008-3015.

Juchem, S. O., F. A. P. Santos, H. Imaizumi, A. V. Pires, and E. C. Barnabe. 2004. Production and blood parameters of Holstein cows treated prepartum with sodium monensin or propylene glycol. J. Dairy Sci. 87:680-689.

McGuffey, R. K., L. F. Richardson, and J. I. D. Wilkinson. 2001. Ionophores for dairy cattle: Current status and future outlook. J. Dairy Sci. 84:194-203.

Melendez, P., J. P. Goff, C. A. Risco, L. F. Archbald, R. Littell, and G. A. Donovan. 2004. Effect of a monensin controlled-release capsule on rumen and blood metabolites in Florida Holstein transition cows. J. Dairy Sci. 87:4182-4189.

NRC. 2001. Nutrient Requirements of Dairy Cattle. 7th rev. ed. Natl. Acad. Sci., Washington, DC.

Nielsen, N. I., and K. L. Ingvartsen. 2004. Propylene glycol for dairy cows. A review of the metabolism of propylene glycol and its effects on physiological parameters, feed intake, milk production and risk of ketosis. Anim. Feed Sci. Technol. 115:191-213.

Overton, T. R., and M. R. Waldron. 2004. Nutritional management of transition dairy cows: Strategies to optimize metabolic health. J. Dairy Sci. 87:105-119.

Ramanzin, M., L. Bailoni, S. Schiavon, and G. Bittante. 1997. Effect of monensin on milk production and efficiency of dairy cows fed two diets differing in forage to concentrate ratios. J. Dairy Sci. 80:1136-1142.

Stephenson, K. A., I. J. Lean, M. L. Hyde, M. A. Curtis, J. K. Garvin, and L. B. Lowe. 1997. Effect of monensin on the metabolism of periparturient dairy cows. J. Dairy Sci. 80:830-837.

Tedeschi, L. O., D. G. Fox, and T. P. Tylutki. 2003. Potential environmental benefits of ionophores in ruminant diets. J. Environ. Qual. 32:1591-1602.

Vallimont, J. E., G. A. Varga, A. Arieli, T. W. Cassidy, and K. A. Cummins. 2001. Effects of prepartum somatotropin and monensin on metabolism and production of periparturient Holstein dairy cows J. Dairy Sci. 84:2607-2621.

Wattiaux, M. A., E. V. Nordheim, and P. Crump. 2005. Statistical evaluation of factors and interactions affecting dairy herd improvement milk urea nitrogen in commercial Midwest dairy herds. J. Dairy Sci. 88:3020-3035.

Wildman, E. E., G. M. Jones, P. E. Wagner, R. L. Boman, H. F. Troutt Jr., and T. N. Lesch. 1982. A dairy cow body condition scoring system and its relationship to selected production characteristics. J. Dairy Sci. 65:495-501. 